Title:

Hydrogen Fueling Station Development and Demonstration

Author(s):

Fred J. Edeskuty, ESA WE

David Daney, ESA/CON

Mark Daugherty, ESA EPE

Dallas Hill, ESA EPE

F. Coyne Prenger, ESA EPE

Submitted to:

DOE Office of Scientific and Technical Information (OSTI)

DISTRIBUTION OF THS DOCUMENT IS UULMTTED
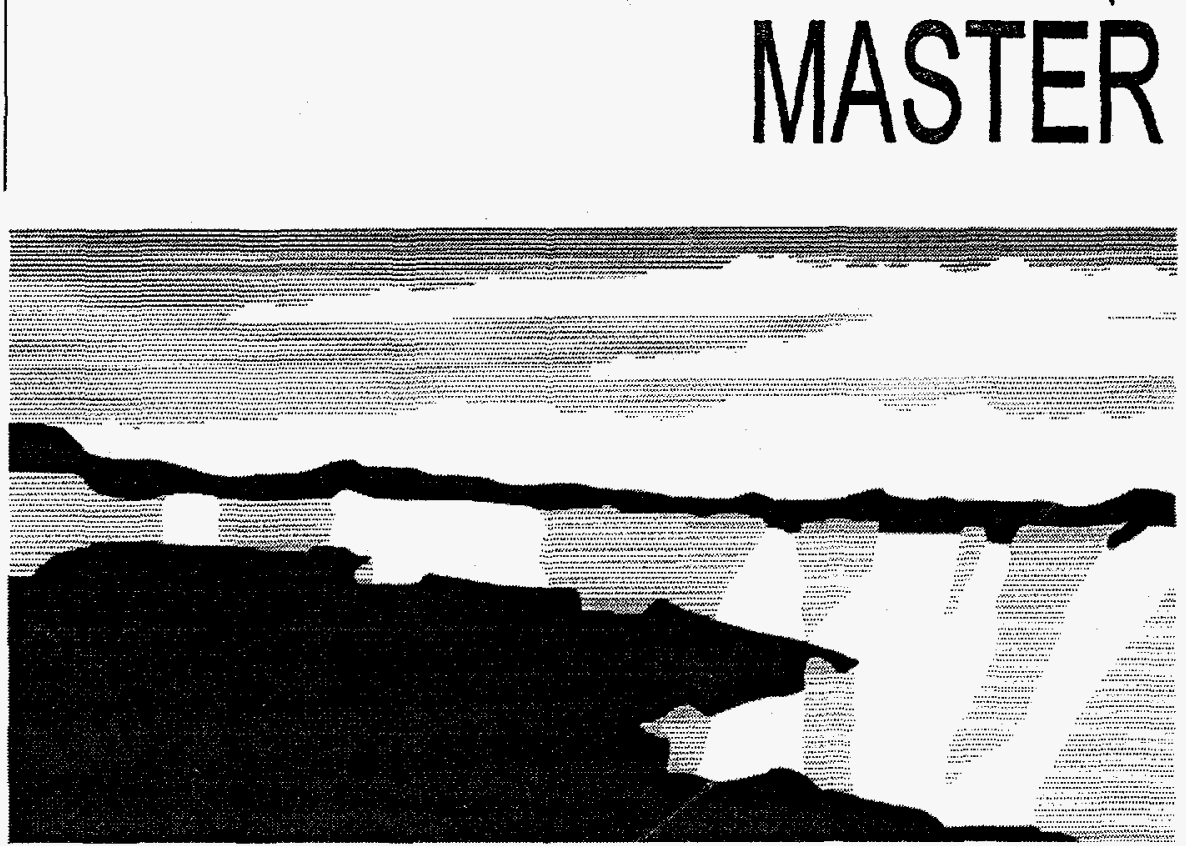

Los Alamos National Laboratory, an affirmative action/equal opportunity employer, is operated by the University of California for the U.S. Department of Energy under contract W-7405-ENG-36. By acceptance of this article, the publisher recognizes that the U.S. Government retains a nonexclusive, royaltyfree license to publish or reproduce the published form of this contribution, or to allow others to do so, for U.S. Government purposes. The Los Alamos National Laboratory requests that the publisher identify this article as work performed under the auspices of the U.S. Department of Energy. 


\section{DISCLAIMER}

This report was prepared as an account of work sponsored by an agency of the United States Government. Neither the United States Government nor any agency thereof, nor any of their employees, makes any warranty, express or implied, or assumes any legal liability or responsibility for the accuracy, completeness, or usefulness of any information, apparatus, product, or process disclosed, or represents that its use would not infringe privately owned rights. Reference herein to any specific commercial product, process, or service by trade name, trademark, manufacturer, or otherwise does not necessarily constitute or imply its endorsement, recommendation, or favoring by the United States Government or any agency thereof. The views and opinions of authors expressed herein do not necessarily state or reflect those of the United States Government or any agency thereof. 


\section{DISCLAIMER}

Portions of this document may be illegible in electronic image products. Images are produced from the best available original document. 


\title{
Hydrogen Fueling Station Development and Demonstration
}

Fred J. Edeskuty*, David Daney**, Mark Daugherty, Dallas Hill, and F. Coyne Prenger

\begin{abstract}
This is the final report of a one-year, Laboratory-Directed Research and Development (LDRD) project at the Los Alamos National Laboratory (LANL). This project sought to develop and demonstrate a hydrogen fueling station for vehicles. Such stations are an essential infrastructural element in the practical application of hydrogen as vehicle fuel, and a number of issues such as safety, efficiency, design, and operating procedures can only be accurately addressed by a practical demonstration. Regardless of whether the vehicle is powered by an internal combustion engine or fuel cell, or whether the vehicle has a liquid or gaseous fuel tank, the fueling station is a critical technology that is the link between the local storage facility and the vehicle.
\end{abstract}

\section{Background and Research Objectives}

Because of the need to improve urban air quality, hydrogen-fueled vehicles have become a subject of increasing interest in recent years; in fact, a number of demonstration projects are planned or in progress around the world. Hydrogen fueling stations are essential to a practical demonstration of these vehicles. Furthermore, only a practical demonstration can accurately and convincingly address a number of issues such as safety, efficiency, design, and operating procedures. Regardless of whether the vehicle is powered by an internal combustion engine or fuel cell, or how hydrogen is stored on-board, the fueling station is the critical technology that links the local hydrogen storage facility and the vehicle.

The goal of the project was to develop and demonstrate a hydrogen fueling station for vehicles, with an emphasis on developing a conceptual design of the fueling station and to model the fuel transfer process for both liquid and gaseous hydrogen refueling. As an aid to specifying design parameters for the $\mathrm{H}_{2}$ delivery system, we also developed a complementary model of vehicle fuel efficiency.

\footnotetext{
* Principal investigator

** Point of contact, e-mail: daney@lanl.gov
} 
A fundamental assumption guiding the project was that the station should receive hydrogen in liquid $\left(\mathrm{LH}_{2}\right)$ form because of near-term economics, which result from the favorable weight and volume advantages that accrue from shipping liquid rather than gas. This view is confirmed by our conversations with United States industry (which delivered 92 percent of non-pipeline merchant hydrogen as liquid in 1993 [1]) and by systems studies (which favor $\mathrm{LH}_{2}$ supplied fueling stations for capacities up to about 300 vehicles/day [2]). At least three methods of onboard fuel storage (liquid, compressed gas, and metal hydride) are under consideration. Because it is unclear what the preferred method will be, or if there will be only one method, we are designing our fueling station to deliver hydrogen as either a liquid, high-pressure gas, or low-pressure gas so that it can accommodate vehicles with any type of fuel tank. Figure 1 illustrates the LANL fueling station concept.

\section{Importance to LANL's Science and Technology Base and National R\&D Needs}

This project supports Los Alamos core competencies in analysis and assessment as well as theory, modeling, and high-performance computing. The Department of Energy (DOE) anticipates that within the next century the United States will complete a transition to a sustainable energy system with hydrogen as a cornerstone, and the Congress has given substance to that goal through the Hydrogen Research, Development, and Demonstration Act. Development of hydrogen fueling station technology tops the list of near-term (5-8 years) demonstration projects recommended by the Hydrogen Technical Advisory Panel. Because it is the cleanest of fuels, the transition to hydrogen (and the need for hydrogen fueling stations) is also strongly driven by the Clean Air Act. Los Alamos occupies a unique position among DOE and Federal Laboratories to carry out the development of a hydrogen fueling station because of our combination of facilities and personnel experienced with handling bulk quantities of liquid hydrogen.

\section{Scientific Approach and Results to Date}

Our approach was to investigate $\mathrm{H}_{2}$ fueling-station technology and safety through a practical demonstration. Thus, we planned to build a fueling station and test it to discover problems, investigate operating parameters, and demonstrate safety. We developed a conceptual design of the fueling station to serve as the basis for modeling liquid and gaseous transfer, safety analysis, and identification and pricing of major components. Hydrogentransfer models for both liquid and gas were developed as design tools. A complementary model of vehicle fuel efficiency as a function of the on-board storage method (liquid, 
compressed gas, or hydride) was developed as an aid for specifying design parameters for the $\mathrm{H}_{2}$ delivery system.

Vehicle-tank-fill rates are important since refueling times must be short (less than five minutes) if the motoring public is to accept hydrogen fuel. In the case of vehicles with liquid tanks, properly selected transfer- and vent-line sizes will give the required fill rates if venting is allowed. Because venting wastes hydrogen and is a minor safety hazard, no-vent filling is preferred. With no-vent filling, however, both the degree of subcooling of the liquid in the supply tank and the amount of assist from a transfer pump strongly influence the fill rate. In the case of compressed gas vehicle tanks, fast filling causes significant adiabatic warming in the tank that results in under filling. With compressed natural gas tanks, under filling by as much as 20 percent is possible [3]. With hydrogen, because of its higher ratio of specific heats, under filling by as much as 30 percent can be expected.

\section{Liquid Transfer}

Our liquid-hydrogen-transfer model is based on a computer code developed by Daney and co-workers at the National Institute of Standards and Technology [4], which simulates both vented- and non-vented transfer between the fueling station supply tank and the vehicle tank. It is a thermodynamic model developed from the differential mass and energy balances applied to both the fueling station supply tank and vehicle tank, and it uses actual hydrogen properties. We consider both single-phase conditions in the vehicle tank (that occur during the initial cool down of an empty tank) and two-phase conditions (that occur after liquid begins to collect in the tank). Either pump-assisted or pressure-induced $\mathrm{H}_{2}$ transfer can be analyzed. The program accepts a wide range of input variables, including heat leaks, tank temperatures, and piping and equipment specifications.

We used our liquid transfer model to investigate the effects on transfer time of the initial conditions in the vehicle tank, the pressure and degree of subcooling in the supply tank, transfer-pipe size and configuration, and transfer-pump power. Figure 2 shows the rise in vehicle tank pressure during a pump-assisted, no-vent transfer, illustrates the detail inherent in the model. Figure 3 gives the transfer time as a function of supply tank subcooling and initial pressure difference, illustrates the importance of subcooling for transfer without assistance from a pump. Close to $0.9 \mathrm{~K}$ of subcooling is required, and more is desirable if there is no pump to assist the transfer. For the 1/2-inch line in these simulations, rapid (below 5 minute) transfer is feasible with good subcooling. Figure 4 shows that use of a centrifugal transfer pump can further reduce the transfer time as well as extend the supply tank operating range to considerably lower subcooling requirements. For vented transfer, of course, no subcooling is required in the supply tank. Figure 5 gives transfer time as a function of transfer pipe size, 
illustrates how the model aids in the design of individual components. A 16-mm (5/8-inch) outside-diameter transfer-line size appears to be a good compromise between fast transfer times and easily handled flexible lines with low mass, and thus, low heat capacity.

\section{Gas Transfer}

The warming that occurs in a compressed-gas, hydrogen-vehicle tank during a fast fill with ambient temperature $(300 \mathrm{~K})$ gas is illustrated in Figure 6 . The curve represents the limiting case of negligible heat transfer from the gas to the tank wall, such as would be the case during rapid filling. The associated under filling of the tank is illustrated in Figure 7. Because the weight and volume penalties associated with compressed-gas vehicle tanks degrade vehicle performance [5], reducing the loss of capacity due to fast filling becomes particularly important. Precooling the fill gas to $214 \mathrm{~K}$ holds the gas in the tank at ambient temperature, thus eliminating the problem of under filling.

\section{Vehicle Performance Model}

The three standard options for storage of hydrogen fuel on passenger vehicles are compressed gas, metal hydride, and cryogenic liquid storage. Our model estimates the performance of hydrogen powered vehicles as a function of storage system weight and vehicle range. Three vehicles were modeled: a metro commuter, a mid-size sedan, and a full-size van. All vehicles are powered by a fuel cell and an electric drive train. The influence of auxiliary power requirements for air conditioning were also examined. In making these comparisons we use the Environmental Protection Agency urban dynamometer driving schedule to represent typical urban driving conditions. Figure 8 shows the effect of on-board hydrogen storage method on vehicle range for a mid-size sedan. Figure 9 shows the effect of storage method on fuel cell size.

\section{References}

1. Heydorn, B., "Hydrogen", in Chemical Economics Handbook, SRI International, Menlo Park, CA (1994).

2. Ogden, J.M., E. Dennis, M. Steinbugler, and J.W. Strohbehn, "Hydrogen Energy Systems Studies," Technical Report, Center for Environmental Studies, Princeton University, Princeton, NJ (1995).

3. Kountz, K.J., "Modeling the Fast Fill Process in Natural Gas Vehicle Storage Cylinders," presented at 207th ACS National Meeting-Division of Fuel Chemistry, San Diego (1994). 
4. Louie, B., N.J. Kemp, and D.E. Daney, "Cryogenic Propellant Scavenging", NBS Technical Report NBSIR 85-3023, National Bureau of Standards, Boulder, CO (1985).

5. Daugherty, M.A., F.C. Prenger, D.E. Daney, F.J. Edeskuty, and D.D. Hill, "A Comparison of the Overall Energy Efficiency of On-Board Hydrogen Storage Systems using the EPA Urban Driving Schedule," paper FR-S1-5, CEC/ICMC (1995).

\section{Publications}

Mark A. Daugherty, F. Coyne Prenger, David E. Daney, Dallas D. Hill, and Fred J. Edeskuty, "A Comparison of Hydrogen Vehicle Storage Options Using the EPA Urban Driving Schedule," Advances in Cryogenic Engineering, submitted, (1996), Los Alamos Report LA-UR 95-2462.

David E. Daney, Fred J. Edeskuty, Mark A. Daugherty, F. Coyne Prenger, Dallas D. Hill, "Hydrogen Vehicle Fueling Station," Advances In Cryogenic Engineering, submitted, (1996), Los Alamos Report LA-UR 95-2464. 


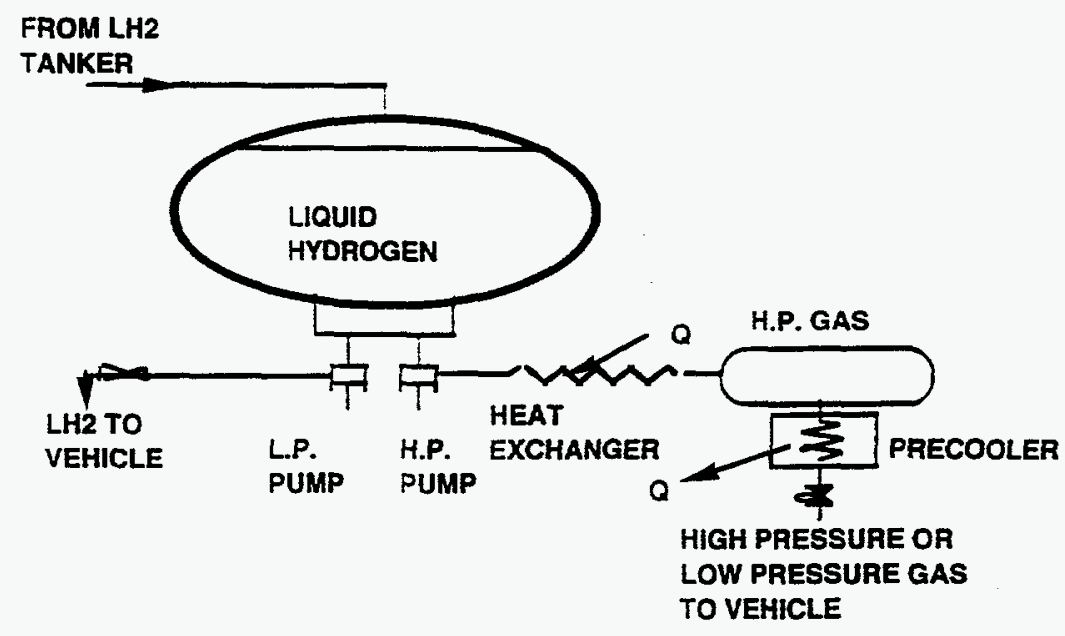

Figure 1. Los Alamos hydrogen fueiing station concept.

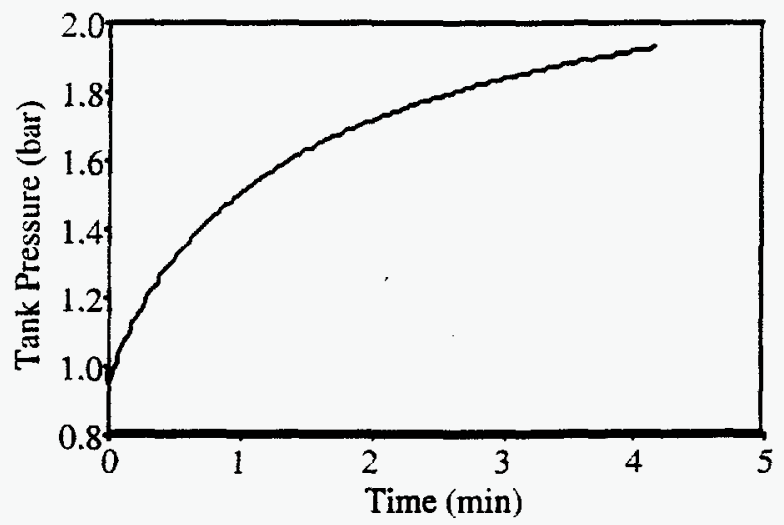

Figure 2. Typical calculated pressure history of the vehicle tank during pump-assisted, no-vent LH2 transfer with $1.0 \mathrm{~K}$ of subcooling. Initial vehicie tank pressure is $1.0 \mathrm{bar}$. Initial pressure difference is 1.0 bar. Pump power is $20 \mathrm{~W}$ and line ID is $10.9 \mathrm{~mm}$.

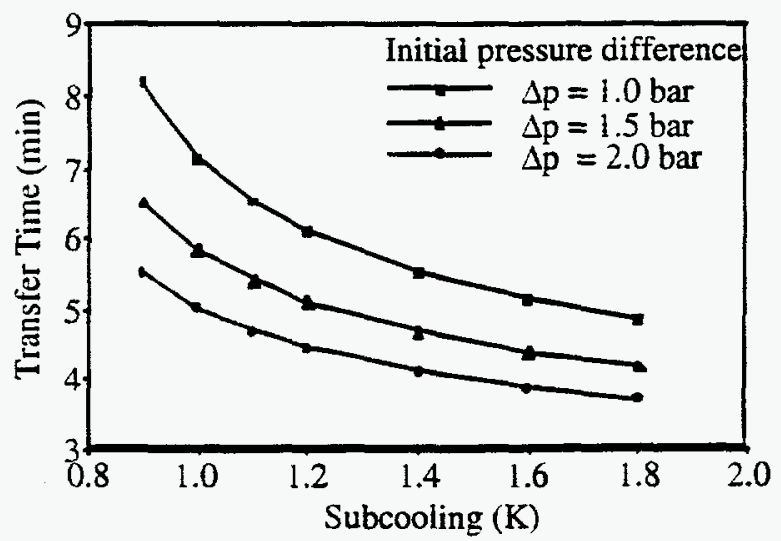

Figure 3. Effect of supply tank subcooling on caiculated LH2 transfer time for no-vent pressure transfer. Initial vehicle tank pressure is $1.0 \mathrm{bar}$ and line ID is $10.9 \mathrm{~mm}$. 


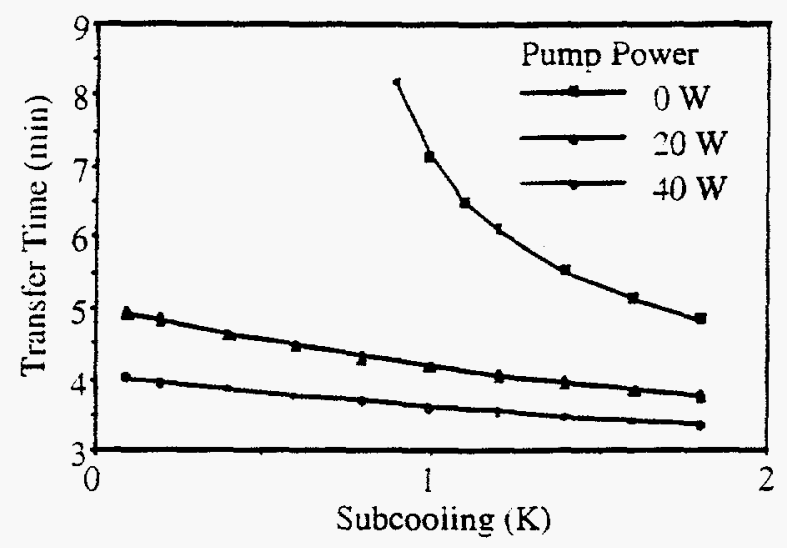

Figure 4. Effect of transfer-pump power on calculated LH2 transier time for no-vent transfer. Initial pressure difference is 1.0 bar. Initial vehicle tank pressure is 1.0 bar and line ID is $10.9 \mathrm{~mm}$.

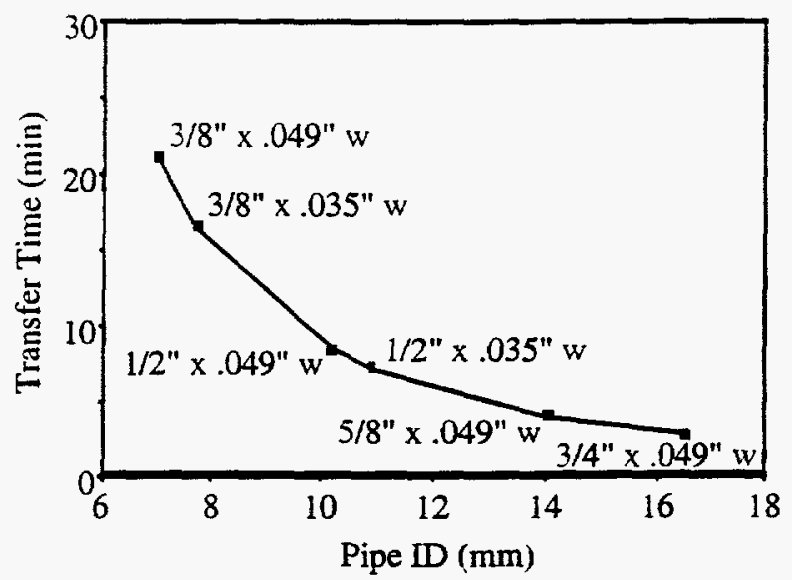

Figure 5. Calculated dependence of LH2 transfer time on pipe diameter for no-vent pressure transfer. The degree of subcooling is $1.0 \mathrm{~K}$. The geometry is: $9.2 \mathrm{~m}$ of straight pipe, $2.6 \mathrm{~m}$ of flexible pipe, eight elbows and five globe valves.Nominal pipe sizes and wall thicknesse are as indicated.

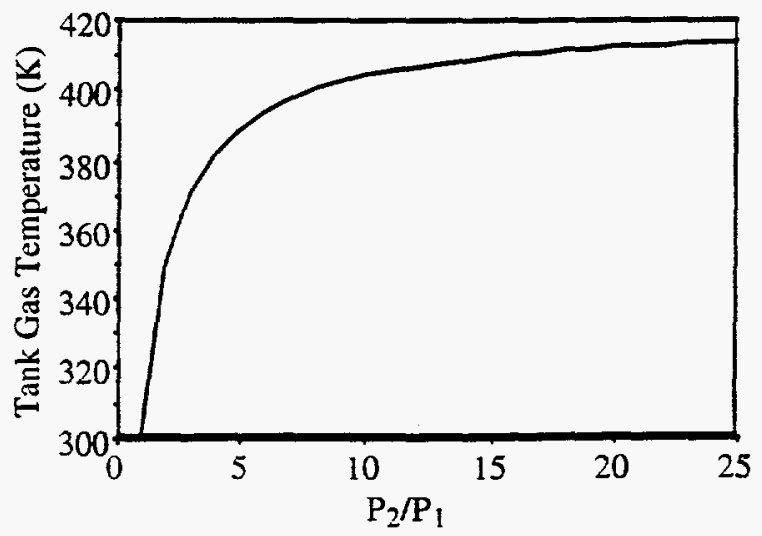

Figure 6. Warming in a GH2 fuel tank during fast fill. These caiculations are for the limiting adiabatic case. 


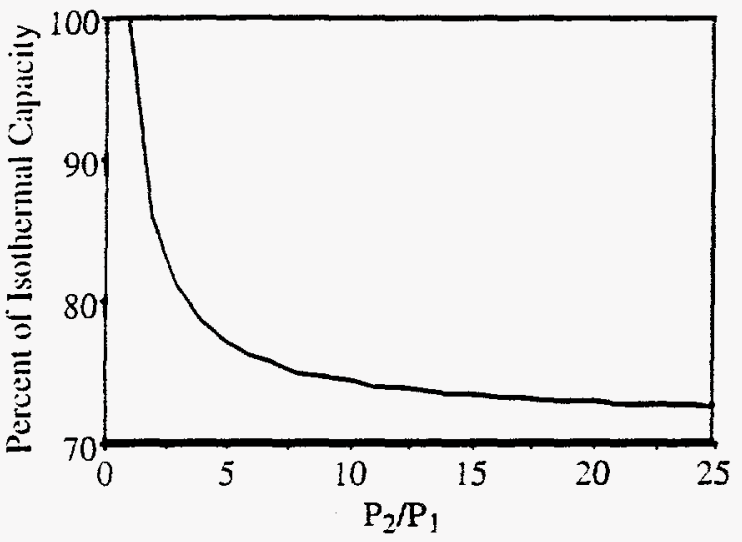

Figure 7. Calculated percent of isothermal GH2 tank capacity that results from an adiabatic fill. The asymptote at high pressure ratios is 71.4 percent full.

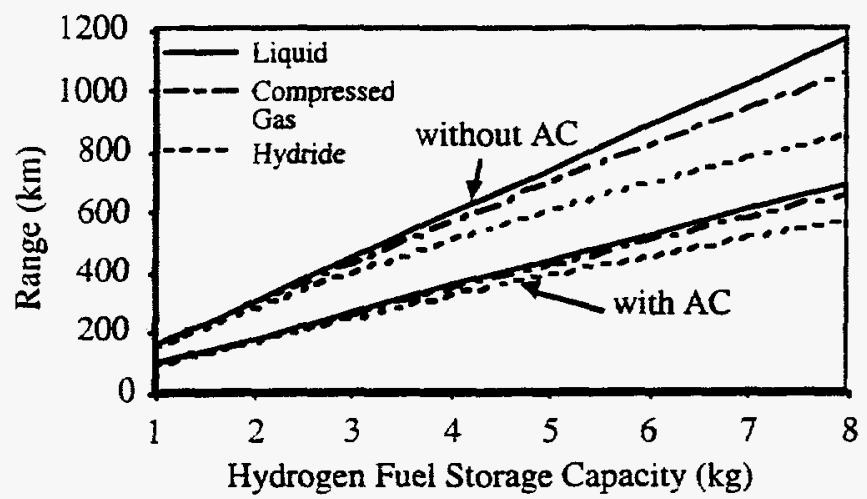

Figure 8. Mid-size sedan range as a function of hydrogen storage capacity. (Top three curves without air conditioning, bottom three with air conditioning.)

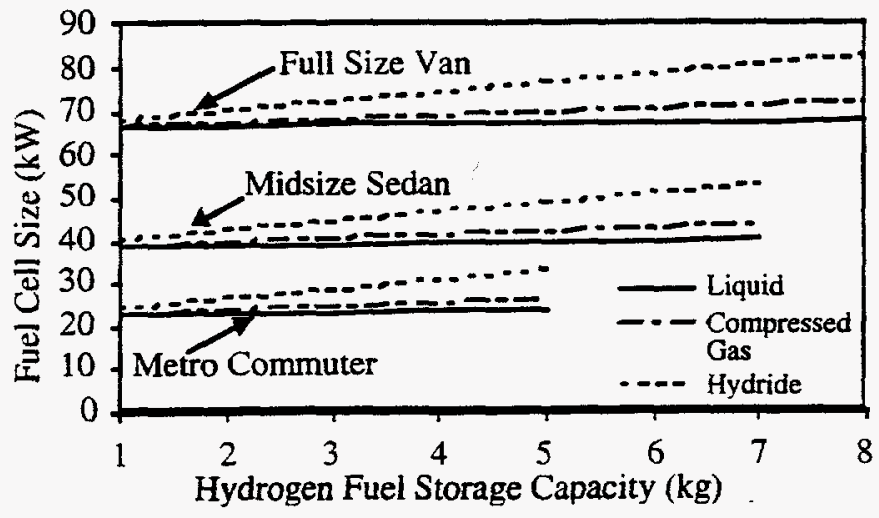

Figure 9. Fuel cell size as a function of hydrogen storage capacity. 